and plasma pancreatic polypeptide in man. Scand $J$ Gastroenterol 1984; 19: 24-30.

4 Andriulli A, Masoero G, Amato A, et al. Serum immunoreactive cationic trypsinogen response to secretin in normal subjects Am J Gastroenterol 1983; 78: 579-83.

5 Koop H. Serum levels of pancreatic enzymes and their clinical significance. Clin Gastroenterol 1984; 13: 739-61.

6 Lesi C, Scandellari A, Cucci AM et al. Changes in serum pancreatic enzymes after hormonal stimulation in chronic pancreatitis. Dig Dis Sci 1985; 30: 552-7.

7 Hafkenscheid JCM, Hessels M, Jansen JBMJ, Lamers CBHW. Serum trypsin, alpha-amylase and lipase during bombesin stimulation in normal subjects and patients with pancreatic insufficiency. Clin Chem Acta 1984; 136: 235-40.

8 Balldin G, Borgstrom A, Eddeland A, Genell S. Hagberg $\mathrm{L}$, Ohlsson $\mathrm{K}$. Elevated serum levels of pancreatic secretory proteins in cigarette smokers after secretion stimulation. J Clin Invest 1980; 66: 159-62.

\section{Tripotassium dicitrato bismuthate on unhealed duodenal ulcers}

SIR,-I read with great interest the work of Bianchi Porro and coworkers.' In the light of the rapidly accumulating evidence of association between peptic ulcer disease and Campylobacter pylori ${ }^{2-4}$ I was disappointed, however, not to find any mention of this. Comparable findings have been reported earlier ${ }^{5}$ and raised the question whether Campylobacter pylori is responsible for those cases of peptic ulcer disease that tend to become chronic and recurrent. It would have been interesting to know whether the results of this study correlate with eradication of Campylobacter pylori from the stomachs of the patients.

FRED KONIKOFF

Dept of Gastroenterology,

Tel Aviv Medical Center,

6 Weizman Street,

Tel Aviv, Israel

\section{References}

1 Bianchi Porro G, Parente F, Lazzaroni M. Tripotassium dicitrato bismuthate (TDB) versus two different dosages of cimetidine in the treatment of resistant duodenal ulcers. Gut 1987; 28: 907-11.

2 Marshall BJ. Campylobacter pyloridis and gastritis. J Infect Dis 1986; 153: 650-7.

3 Rathbone BJ, Wyatt JI, Heatley RV. Campylobacter pyloridis - A new factor in peptic ulcer disease? Gut 1986; 27: 635-41.

4 Hornick RB. Peptic ulcer disease: A bacterial infection? $N$ Engl J Med 1987; 316: 1598-600.

5 McNulty CAM, Gearty JC, Crump B, et al. Campylobacter pyloridis and associated gastritis: investigator blind, placebo controlled trial of bismuth salicylate and erythromycin ethylsuccinate. $\mathrm{Br} \mathrm{Med} J$ 1986; 293; 645-9.
Reply

SIR,-We thank Dr Konikoff for his letter regarding our article (Gut 1987; 28: 807-911). We agree with his interest to evaluate in future clinical trials, on duodenal ulcer resistant to $\mathrm{H}_{2}$-blockers, the role of Campylobacterpylori (CP) colonisation in developing refractoriness. Unfortunately, this could not be done in our study, because when the trial was planned (August 1984), a reliable method to detect CP in our laboratory was not yet available.

Indirect information on this topic, however, can be drawn from our recent experience on the relationship between eradication of campylobacter from the antrum and the duodenal bulb and duodenal ulcer healing induced by tripotassium dicitrate bismuthate (TDB); 49 patients with active duodenal ulcer have been treated with DeNol $480 \mathrm{mg} / \mathrm{d}$ for four weeks; the presence of campylobacter in single biopsy specimens from duodenal bulb and gastric antrum was investigated by CLO test which has been documented to be an accurate predictor of the presence of $\mathrm{CP} ;{ }^{12}$ the test was done on each patient at the initial and the follow up endoscopy.

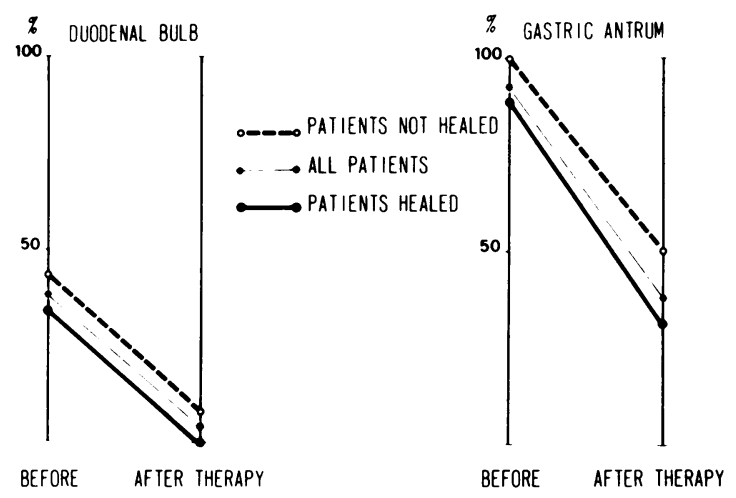

Ninety two per cent and $37 \%$ of patients, respectively, had a positive antral and duodenal CLO test on study admission; after four weeks of treatment, the corresponding percentages of positivity were $37 \%$ and $2 \%$, respectively. Evaluating the percentage of campylobacter eradication separately in healed and non-healed patients, we have not found any significant difference between the two groups. In fact, in non-healed ulcers antral CP positive specimens were $100 \%$ and $50 \%$ before and after treatment, while duodenal CP positive biopsies were $43 \%$ and $7 \%$, respectively; the corresponding figures in healed ulcers were $89 \%$ and $31 \%$ for the antrum and $34 \%$ and $0 \%$ for the duodenal bulb (Figure). These findings suggest that the healing process, at least in responder duodenal ulcers, is not clearly related to 
CP eradication from the gastric antrum or the duodenal bulb.

G BIANCHI PORRO

F PARENTE

M LAZZARONI

Gastrointestinal Unit,

L. Sacco Hospital,

Via G B Grassi, 74,

20157 Milano, Italy

\section{References}

1 Borromeo M, Lambert JR, Pinkard KJ. Evaluation of "CLO-test" to detect campylobacter pyloridis in gastric mucosa. J Clin Pathol 1987; 40: 642-548.

2 Borsch G, Adamek R, Sandmann M, et al. Comparison of biopsy urease test and histologic examination for detection of campylobacter pylori in duodenal, antral and fundic biopsies. Hepato-Gastroenterol 1987; 34: 236-41.

\section{Bile acid malabsorption in progressive systemic sclerosis}

SIR,-We have read with interest the paper by Stellaard and coworkers ${ }^{1}$ on the increase of unconjugated serum bile acids in patients suffering from progressive systemic sclerosis. (PSS). We have recently studied the serum pattern of primary bile acids in PSS-patients and the results have been partly reported on the journal of the Italian Association of Rheumathology ${ }^{2}$ and at international symposia. ${ }^{34}$

Our data confirm that a bile acid malabsorption is, in these patients, much more frequent than it is usually believed. We also think that malabsorption can not be caused only by bowel bacterial overgrowth. Very often the clinical picture of malabsorption is not reversed by wide spectrum antibiotics and in most patients steatorrhoea persists despite treatment.

In a group of 11 patients with 'classical' PSS (ARA criteria) we evaluated serum conjugated primary bile acids concentrations (by RIA) after an overnight fast and during three hour after a standard semiliquid meal (450 cal.). Postprandial curves were compared with 10 curves from sex and age matched healthy controls. Fasting serum concentrations of chenodeoxycholic acid conjugated (CDCA) were similar in the two groups $[1.76(1.0) \mu \mathrm{mol} / 1$ in controls, $1.42 \pm 0.75 \mu \mathrm{mol} / \mathrm{l}$ in PSS], while the concentrations of cholic acid conjugated (CCA) were lower in the PSS-group $[0.67(0.23) v 0.48(0.17) \mu \mathrm{mol} / \mathrm{l} . \mathrm{p}<0.05]$. A similar pattern was exhibited by the postprandial increases postprandial maximal peaks of CDCA were almost normal in patients with PSS [6.59 (2.18) in controls, $5.19(2.99)$ in PSS], while CCA peaks were strongly reduced in PSS-patients $[3.36(0 \cdot 65) v$ $1.35(0.44), \mathrm{p}<0.001]$.
Similarly, the area under the curve calculated for serum post-prandial concentrations of CDCA was not significantly different in the two groups, while for CCA concentrations, the area was significantly smaller in PSS-patients $(\mathrm{p}<0.01)$.

In five patients we also studied the abdominal retention of ${ }^{75} \mathrm{SeHCAT}\left({ }^{75} \mathrm{Se}\right.$-homocholic acid taurine) at the fourth and the seventh day after the ingestion of a $370 \mathrm{kBq}(10 \mu \mathrm{Ci})$ capsule (Amersham). PSS-patients exhibited strongly reduced ${ }^{75} \mathrm{SeHCAT}$ abdominal retention (at seventh day: mean $5 \cdot 53 \%$, range 1-14) when compared with five sex and aged matched healthy controls (mean $23.30 \%$, range 11.4-33). The results of ${ }^{75} \mathrm{SeHCAT}-$ test were in good agreement with serum postprandial patterns of CCA.

Because it is well known that negligible bacterial deconjugation of SeHCAT occurs in vivo, bowel bacterial overgrowth does not seem to be important in determining bile acid malabsorption in PSS.

Our data are consistent with a bile acid malabsorption of first type, very similar to that found to be related to Crohn's disease or to ileal resection ${ }^{5}$ and the severity of malabsorption may depend on the extent of ileal involvement in PPS.

In conclusion, we suggest that fasting and postprandial serum concentrations of CCA and ${ }^{75}$ SeHCAT abdominal retention test represent good markers of ileal disease in these patients. We therefore agree with Stellaard and coworkers, that further studies should be done to investigate the specific role of bacterial overgrowth in PSS, particularly with cholyl-glycine- $1-{ }^{14} \mathrm{C}$ breath test.

\section{P PAZZI \\ S PUTINATI \\ B BAGNI \\ M GOVONI \\ F TROTTA}

1 Divisione Medicina,

Servizio di Medicina Nucleare and

Divisione di Reumatologia,

USL 31, Arcispedale S Anna,

Corso Giovecca 203,

44100 Ferrara, Italy

\section{References}

1 Stellaard F, Sauerbruch T, Luderschmidt CH, Leisner B, Paumgartner G. Intestinal involvement in progressive systemic sclerosis detected by increased unconjugated serum bile acids Gut 1987; 28: 446-50.

2 Trotta F, Pazzi P, Govoni, et al. Valore diagnostico degli acidi biliari sierici nello studio del malassorbimento in corso di malattia sclerodermica. Reumatismo 1985; 37: 149-59. 